\title{
The Importance of 'Teacher Talk' in Teaching EFL Writing
}

\author{
Mohammad AghajanZadeh Kiasi \\ FATEMEH HeMmati \\ Payame Noor University, Iran
}

Received: 16 December 2012 / Accepted: 30 July 2013

ISSN: $1697-7467$

\begin{abstract}
The significance of teacher talk should be seriously valued and investigated, especially for the purpose of teaching those skills in which language learners are heavily dependent on the input and instruction received from the teacher. The current study explores English language teacher discourse from a pedagogical perspective in English writing classes. The investigation undertaken based on Analysis of Speech units revealed three distinct pedagogical episodes, namely Focal, Remedial, and Notional talk. By these three modes writing teachers can orally fulfill their pedagogical purposes of teaching, recovering and evaluating the linguistic and ideational structures by either text-directed or non-text directed speech.
\end{abstract}

Keywords: Analysis of speech units, episodes, inhibition hypothesis, micro-episodes, writing teacher talk.

La importancia del habla del profesor en la enseñanza de la escritura del inglés como lengua extranjera

RESUMEN: La importancia del habla del profesor debe de ser valorada e investigada con seriedad, especialmente para el propósito de enseñar las habilidades en las que los estudiantes de lenguas dependen fundamentalmente del input y la instrucción que reciben del profesor. Este estudio exploró el discurso del profesor de inglés desde una perspectiva pedagógica en las clases de escritura en inglés. La investigación sobre la base de las unidades de análisis reveló tres episodios pedagógicos distintos: focal, remediación, y habla nocional. A través de estos tres modos, los profesores de escritura pueden cumplir con sus fines educativos de enseñanza oral, recuperar y la evaluar las estructuras lingüísticas e ideacionales, ya sea dirigido o no dirigido por el texto.

Palabras clave: Análisis de las unidades del habla, episodios, hipótesis de la inhibición, micro-episodios, la escritura del habla del profesor.

\section{INTRODUCTION}

Teacher talk is an indispensible part of language teaching in an EFL (English as a Foreign Language) context which can bring about significant instructional benefits for teachers when applied meticulously and learning opportunities for language learners when noticed purposefully. It can potentially lead to success or failure in teaching and meeting learner needs as Nunan (1991) asserts: 
Teacher talk is of crucial importance, not only for the organization of the classroom but also for the processes of acquisition. It is important for the organization and management of the classroom because it is through language that teachers either succeed or fail in implementing their teaching plans. In terms of acquisition, teacher talk is important because it is probably the major source of comprehensible target language input the learner is likely to receive. (p.189)

Also, the importance of teacher talk and its instructional components have been implied by Stern (1983) who claims that the language teacher's capability of teaching is determined by language background, previous language teaching experience and formulated theoretical presuppositions about language learning and teaching. All these mentioned characteristics can affect the quality and effectiveness of teacher talk, which is regarded as the major medium of instruction.

A large number of publications and studies on teacher language awareness have focused on the forms and grammatical aspects of teacher talk regardless of the kind of language skill taught to language learners (Murray,2002; Breidbach, Daniela and Andrea, 2011; Chadwick, 2012). How this awareness-raising should be deployed to boost a specific language skill of language learners is what that has not extensively been discussed in language teaching publications and forums. Further, teacher talk has widely been investigated in terms of its discoursal and interactional features with a focus on the IRF (Initiation-Response-Feedback) exchange (Warford, 2007; Nakaruma, 2008; Hale, 2011), regardless of its instructional and pedagogic impacts on teaching a specific language skills such as writing. However, Andrews (2003) has defined teacher language awareness as teacher's knowledge about various linguistic components and the subject matter. This broad view is obviously manifested in carefully context-embedded teacher talk in which teachers can have a range of potential options to manage students' language learning input through purposeful coverage of relevant pedagogic features, hence affecting their learning quality.

Communicative approaches to language teaching may depict teacher talk, aside from its scaffolding role, as an obstruction when it reduces students' active participation. However, teachers can utilize their talk and make it constructive through a controlled use of their talk (Walsh, 2002). Hall (2011) holds the opinion that the amount of teacher talk should be discussed not only in term of control and management but also, more importantly, for the sake of pedagogy and quality of class interaction. This view towards teacher talk can be explained better by Nizegorodcew (2007) who argues that teacher talk provides the learners with second language input mainly by interactional discourse modifications leading to negotiated meaning. Thus, the contextual sensitivity and its role in the manipulation of the language channeled to language learners would be of immense importance for maximizing learning opportunities and compensating for the inherent existence of unequal communicative rights through revealing both the manifest and hidden forms of an English curriculum. To illustrate, a writing program is shaped by either pre-determined criteria to support the intentional instructional agenda or implicit educational norms and individual attitudes which usually differ by context. But expert writing teachers can reflectively organize their discourse and presentations around told and untold language requirements to help all learners meet their own learning aims. 


\subsection{Teacher Talk in Writing}

The inherent task difficulty and complexity of writing skill may deter the learners' oral participations; so, the heavy burden of teaching writing falls on teacher talk which Cullen (1998) finds its quality more important than its quantity in providing an invaluable source of comprehensible input. What is more, the importance of teacher talk in a writing course is not limited to the commonly discussed triadic structure of discourse, IRF, or a quantitative view of teacher talking time (TTT) but its pedagogical potential and appropriacy in relation to what is being taught are also of great importance. Ellis (2003) makes an instructional claim about teacher talk on the grounds that it should coincide with a clear thematic focus and level adjustment. He believes that this deliberate teacher talk brings about opportunities for students' self-regulated comments as it can make students better expose their learning concerns in the form of comments on pedagogical points and other students' presentations.

One of the pedagogy-oriented frameworks for teacher talk has been proposed by Walsh (2006) in which his revised model of Self- Evaluation of Teacher Talk ( SETT) goes beyond the traditional IRF-type analysis and takes four modes of language teaching, namely managerial, material, skills-systems and context into account. However, the framework is not skill-specific inasmuch as all language systems (phonology, discourse, grammar and vocabulary) and language skills (writing, speaking, reading and listening) are embodied in the skills-systems mode. Further, the inseparable concept of context mode has been detached from other modes merely for its role in enabling learners to talk by promoting oral fluency practice and activating mental schemata. Given that teacher talk should be seen a major source of input and pedagogical contents, code-switching is another neglected area in the proposed framework since thematic development of some lessons is carried out through the alternating use of L1 and L2. A full consideration of context and a pedagogy-oriented investigation of teacher talk, especially when it comes to a specific language skill, can doubtless afford teachers and teacher trainers more penetrating and practical insights into this potentially rich source of input. The current study has taken these issues into account and has shown the exclusivity of instructional function of teacher talk in writing skill.

The primary purpose of the current study is to investigate the several instructional and discoursal functions of teacher talk specifically uttered in writing classes. For this aim, the following research question was posed: Does teacher talk in writing classes carry different pedagogical functions.

\section{Data gathering and analysis}

For this study, there was a need to capture a sufficient account of context variability and dynamics of interactional patterns. Thus, Analysis of Speech units was employed as an investigative approach to describing and analyzing the instructional episodes of Writing Teacher Talk (WTT) in the current study. Analysis of Speech units (AS-units) devised by Foster, Tonkyn and Wigglesworth (2000) is applied to analyze a single speaker's utterance. It interestingly deals with disconnected utterances which commonly occur in non-native teacher talk. AS-units also takes accounts of multi-clause unites in which a single purpose is accomplished beyond a single clause. For this study, the first level of AS-units application 
was used because both fragmentary and non-fragmentary utterances were of great importance and huge transactional data without excluding elliptical units, despite principled exclusion of irrelevant utterances, were to be investigated.

The descriptive framework for analyzing the writing teacher talk in this study was gained from a diverse corpus comprising three different sets of college writing sessions held by two expert writing teachers, totaling roughly 18.5 hours of 15 sessions or 15500 words. Several sessions of three different audio-recorded writing instruction contexts were randomly selected: 8 sessions of one teacher's instruction in an advanced academic writing course run for the IELTS (International English Language Testing System) candidates, 4 sessions ( sessions 2,3, 9 and 10) of a basic essay writing course offered to TEFL (Teaching English as a Foreign Language) students at Islamic Azad University of Rasht Branch and finally 3 sessions (sessions 2, 3 and 6) of an introductory English composition course held at University of Guilan in Iran for general purposes of Law students doing a Bachelor of Arts. Both teachers had granted prior permission to record their writing instruction. Data were gathered from these three different contexts to ensure the validity of the research.

In the pre-coding stage, the recorded utterances were transcribed and then were assigned a close reading to find out a structured, formal coding method. To do this, the utterances were systematically marked. For illustration, an AS-unit boundary was shown by an upright slash; a clause boundary was separated by a double colon; and self-corrections or missing words were marked inside the brackets. Thereafter, in initial coding phase a content analysis of texts was applied by an iterative, careful reading of teachers' statements to find pedagogical functions of teachers' utterances. Once the writing- related texts extracted from teacher talk were highlighted, an informative label was attached to each part to provide an explicit description. Each episode comprised a single or collection of utterance given for a major pedagogic purpose such as teaching a new feature of writing or giving feedback to students for their remarks or writings. A Micro-episode was defined as a specific orientation of each episode toward a writing feature such as grammar, vocabulary, ideas and organization. For illustration, the utterance "the last passive sentence is not parallel with the previous senten$c e$ " was regarded as the teacher's idea about a students' writing with a focus on a linguistic feature ( passive structure) and the teacher's preceding utterance "what do you think about his writing?" made this part of teacher talk be labeled as notional-linguistic -text directed. In the third stage two major analyses were done: Firstly, the discovered patterns in academic writing sessions were compared to those of the general English writing course and the basic essay writing one coded by another coder to ensure the credibility of the research, a qualitative alternative to internal validity proposed by Lincoln and Guba (1985) and supported by many research experts such as Fraenkel and Wallen (2003), by making certain that the gathered data is as full and complete as it can be. Secondly, the full data of three randomly selected sessions were coded again by two coders to assure the inter-coder reliability. The results of the interrater analysis $\kappa=0.922$ deriving from .93 total agreement and .23 chance agreement for 91 valid cases suggested a high degree of agreement between two coders, resulting in a robust conclusion in data dependability of the current research.3. Results

Three pedagogic episodes of writing teacher talk (WTT) which instructionally act differently and enjoy distinct discoursal features while teaching writing skill were identified: 
- Focal Talk

- Remedial Talk

- Notional Talk

As to the context of emergence, these episodes are shaped in both text-directed or sample-dependent (when teacher talk is directed to a sample paragraph or essay) and non-text directed contexts (when teacher talk is not referred to any shared text, document or students' writing). Regarding the pedagogical component of writing teacher talk, two micro-episodes were detected: writing tutors can teach either linguistic (grammar, vocabulary, punctuation, etc.) or ideational (ideas, concepts, beliefs, and arguments) issues in their talk. Table 1 provides the summary of identified pedagogical aspects of writing teacher talk.

Table 1: Pedagogical Features of WTT (Writing Teacher Talk)

\begin{tabular}{|c|c|c|}
\hline Episodes & Micro-Episodes & Cont ext \\
\hline $\begin{array}{ll}\text { - } & \text { Notional } \\
\text { - } & \text { Focal } \\
\text { - } & \text { Remedial }\end{array}$ & $\begin{array}{ll}- & \text { Linguistic } \\
- & \text { Ideational }\end{array}$ & $\begin{array}{ll}\text { - } & \text { Text-directed } \\
\text { - } & \text { Non-text-directed }\end{array}$ \\
\hline
\end{tabular}

Both instructional and discoursal features of three pedagogical episodes of teacher talk have been provided distinctly in three tables (See Tables 2, 3, 4). Their related extracts, in which ' $\mathrm{T}$ ' stands for teacher and ' $\mathrm{S}$ ' for student and numbers before these initials show the sequence of participants' turns, have been followed with explanations to illustrate the categorizations. Focal talk is a major part of WTT by which a writing teacher presents new lessons and subjects either linguistically or ideologically (See Table 2). Extracts 1 and 2 illustrate a clear manifestation of this talk.

Table 2: The Focal WTT

\begin{tabular}{|l|c|c|}
\hline $\begin{array}{l}\text { INSTRUCTIONAL } \\
\text { FEATURES: } \\
\text { The teacher: }\end{array}$ & $\begin{array}{l}\text { initiates a talk about how and what to write on a new lesson } \\
\text { refers learners to new materials }\end{array}$ \\
& $\begin{array}{l}\text { asks referential and display questions to direct the teaching } \\
\text { may elicit response despite an absence of learner talk due to } \\
\text { novelty of writing lesson } \\
\text { enables students to produce or write taught structures and style } \\
\text { may restate new materials in a teacher-initiated discourse }\end{array}$ \\
\hline $\begin{array}{l}\text { DISCOURSAL FEA- } \\
\text { TURES: }\end{array}$ & $\begin{array}{l}\text { extended talk, echo ( repetition), confirmation checks, extensive use of } \\
\text { transitional markers, speech modification, scaffolding }\end{array}$ \\
\hline
\end{tabular}

\section{Extract 1}

$01 \mathrm{~T}$ |One of the important factors to improve your essay quality is cohesion or some structures or remarks::to link your ideas|. |You know and have seen these phrases and words| but you don't use them too much.| See the sample in page 38.|I mean two paragraphs, two bodies, one writing.| I bolded the phrases.| 
$02 \mathrm{~S} 1$ |You mean adverbs?|

$03 \mathrm{~T} \mid$ Technically they act differently.| As you see here.| simple word another can link two related sentences.| Let me tell you something strange.| Many students forget this basic structure unfortunately. |They don't change the meaning too much, $\{$ they $\}$ make fluency.

Extract 1 displays the Focal Talk occurring in a text-directed context in which a linguistic structure is going to be taught. But this pedagogic purpose is served in a non sample-dependent or non-text directed teacher talk in Extract 2.

\section{Extract 2}

$01 \mathrm{~T} \mid$ There is a strange structure:: to show your emphasis on your sentence of opinion.| $\mid\{i t\}$ Is called inversion.| This comes with negative adverbs such as never, seldom or rarely.| But the common one is related to not only but also phrases:: that you use usually.|

Another episode of WTT by which a language teacher tries to correct mistakes and solve students' problems in their writings is called Remedial talk. This part of WTT coincides with longer students' oral participation. Its characteristics are provided in Table 3. Extracts 3 and 4 have been brought to present its discoursal and instructional features.

\section{Table 3: The Remedial WTT}

\begin{tabular}{|l|ll|}
\hline INSTRUCTIONAL & $\begin{array}{l}\text { normally responds to student-initiated talk about what has not been } \\
\text { FEATURES: }\end{array}$ \\
The teacher: & $\begin{array}{l}\text { learned carefully } \\
\text { talks to remove the ambiguity of written feedback } \\
\text { talks for the purpose of recovering or boosting students writing } \\
\text { may refer to the previous taught material or Focal WTT (reteach- } \\
\text { ing) when students ask }\end{array}$ \\
& $\begin{array}{l}\text { simplifies the talk adjusting to the students' talk for better under- } \\
\text { standing } \\
\text { promotes the dialogue and discussion }\end{array}$ \\
\hline $\begin{array}{l}\text { DISCOURSAL FEA- } \\
\text { TURES: }\end{array}$ & $\begin{array}{l}\text { formulates content-focused and form-focused responses } \\
\text { reminds student writers of key information }\end{array}$ \\
& $\begin{array}{l}\text { (learner initiates, teacher responds, learner feedbacks to show the } \\
\text { learnality), extensive use of display questions, clarification requests, } \\
\text { confirmation checks, interruptions, scaffolding }\end{array}$ \\
\hline
\end{tabular}

\section{Extract 3}

$01 \mathrm{~S} 1$ |Talking too much about one concept is wrong.| I've seen in many comments

$02 \mathrm{~T} \mid$ it is $\}$ circumlocution $\mid$

$03 \mathrm{~S} 1$ |really is difficult|

$04 \mathrm{~T}$ |you wanna know:: how to solve it.| 
05 S2 |yes.| Any way?|

$06 \mathrm{~T}$ | Maybe it's caused by lack of vocabulary.| So we should improve it,| I said before, especially the content- related ones seen in chapter 7.| Also, we should revise after draft,| I mean reread the paragraph.| Mr. Mayeh has recovered it.| You can compare his second session writing with now.|

$07 \mathrm{~S} 1$ |Sometimes I repeat the meaning of my sentence::as your comments say.| I edit after draft but for the examination?|

$08 \mathrm{~S} 3$ |Yes, we should edit our drafts to improve.| I do brainstorming:: as our teacher said,| it's effective before any body paragraph.|Day by day we can be better.|

$09 \mathrm{~S} 2 \mid\{\mathrm{It}\}$ Needs more thinking.| I try. $\mid$

In extract 3, students 1 and 2 are consciously attempting to correct redundancy and circumlocution, which have been reported as their problems before. Also, Student 3, whose utterance shows the recent mastery of this ability and tangible evidence for a remedial orientation, acts as a collaborator in a non-text directed talk, which was originally initiated by student 1 and terminated by student 2 . On the contrary, in Extract 4 the remedial episode commences with teacher announcement of student writers' errors, in which firstly cohesive signals are reported as students' problems through non-text directed talk; then, the teacher rapidly refers to the same problem in a text-directed talk by drawing attention to the writing of one student

(Danial) as his addressee. The second turn of teacher talk in Extract 4 has also shaped a text-directed remedial episode. The remedial aspect of this extract consists in correcting some errors of one student coinciding with others awareness and involvement. Put simply, the pedagogic components of this type of writing teacher talk are not new but previously taught. This claim holds better true with phrases I've seen in many comments by $\mathrm{S} 1(01)$ and $I$ said before by teacher.

\section{Extract 4}

$01 \mathrm{~T} \mid \mathrm{I}$ saw some mistakes regarding cohesive remarks in your writing::especially those sent to me.| For example, you, Danial, here after "other" we use plural noun.| Instead, we should write " the other advantage" |

02 S1 |or another.| Danial has used "therefore" four times in his essay|

03 S2 |Yes.|Also "thus"|

$04 \mathrm{~T}$ |In this essay you were supposed:: to consider a cause-effect relation.| So using

"therefore" to show the effect seems natural.| But as your friends say| be careful about the repetition.| Normally, you can use some words such as "consequence and upshot":: to link these bad effects.|

Notional talk, as its name suggests, covers a part of writing teacher talk by which writing teachers want to evaluate and express their opinions on several aspects of students' written performances (See Table 4). 
Table 4: The Notional WTT

\begin{tabular}{|l|l|}
\hline $\begin{array}{l}\text { INSTRUCTIONAL } \\
\text { FEATURES: } \\
\text { The teacher: }\end{array}$ & $\begin{array}{l}\text { - debriefs student writers and expresses general opinions on different } \\
\text { writings } \\
\text { - rejects or accepts the student's response explicitly or implicitly, } \\
\text { usually in a typical IRF exchange ( teacher initiates, students responds, } \\
\text { and teacher feedbacks) } \\
\text { - shows the agreement or disagreement with students' statement } \\
\text { - may recast as a remedy or teach a new issue after incorrect answers }\end{array}$ \\
\hline $\begin{array}{l}\text { DISCOURSAL } \\
\text { FEATURES: }\end{array}$ & $\begin{array}{l}\text { elaboration requests, frequent reformulated questioning, brief re- } \\
\text { sponse, multiple addressees, minimal repair, an equal share in rapid } \\
\text { turn- taking, shorter turns, referential question- oriented }\end{array}$ \\
\hline
\end{tabular}

In Extract 5 portraying an episode of Notional Talk a circle of participants' opinion on linguistic features such as style and grammatical structures and finally on concepts and ideas is shaped. This extract shows the likely juxtaposition of linguistic (03 T) and ideational (05 T) utterances in every single episode. Similarly, in Extract 4 both text and non-text directed teacher talk emerged together in the Remedial Talk. Giving feedback and suggestions is the main feature of the Notional Talk, seen in the second turn of teacher $(03 \mathrm{~T})$, by which the teacher confirms the students' opinion (02 S1).

\section{Extract 5}

$01 \mathrm{~T}$ | You, Sam, what do you think about his writing?|

$02 \mathrm{~S} 1$ |[It $\}$ Seems ok| but its intro is short.| I think $\{$ it $\}$ need more words.| Why we have a lot of passive structures in there?

$03 \mathrm{~T} \mid \mathrm{Ya}$, the number of this structure is not the problem| but the last passive sentence is not parallel with the previous sentence.|

04 S2 II can't get the relation of examples in bodies with topic.|

$05 \mathrm{~T}$ |Examples?| You mean Internet and air traveling.| Leila thinks:: these both points of major technological improvements have caused some problems.| It's correct.|

06 S2 |Really are \{they\} negative?|

07 S3 |She has written air traffic and deadly crash for air travelling.| They are common.|

Extract 6 shows an expert transition from the Notional Talk (Good Comment. You're right) to the Focal talk (But when there is an.....), when the teacher asking a referential question as a part of Notional Talk $(01 \mathrm{~T})$ finds students' answer or opinion incorrect (03 $\mathrm{T}$ Why it can be.) and tries to teach a new writing matter $(03 \mathrm{~T}$ Different ideas...., $05 \mathrm{~T}$ But when there....) .

\section{Extract 6}

$01 \mathrm{~T}$ |you think:: we should talk about our opposing idea in our writing?|

$02 \mathrm{~S} 1$ |No,| I think no.| 
Mohammad Aghajanzadeh Kiasi and Fatemen Hemmati $\quad$ The Importance of ‘Teacher Talk'...

$03 \mathrm{~T}$ |Why?| It can be.| Different ideas for one matter.|

04 S2 |No.| Because when we want:: to describe a situation or an object,| we can't talk about different opinions.| Because it is fixed.|

$05 \mathrm{~T}$ |Good comment.| You're right.| But when there is an argument.| it is clear:: that different people have different ideas regarding one matter.| It's certain:: we'd better:: write about different sides:: because it's a matter of controversy.| This essay (teacher shows the writing to the students) is really more convincing.| Take it seriously.|

One major part of Notional Talk can be questioning which possibly leads to other episodes of teacher talk, Focal and Remedial, as can be seen in Extract 6. Many ways have been created to categorize questions applied in the classroom. Richards and Lockhart (2007) offer the terms procedural, convergent and divergent. They explain that procedural questioning refers to the management of the classroom and lesson, which cannot be discussed in this study as it serves no role in pedagogical practices. Convergent questions encourage short answers mainly for the purpose of focusing on the recall of previously presented materials or lessons, not for generating concepts and idea or natural communication whereas divergent questions "require students to engage in higher-level thinking" (p.187). By divergent questions students are supposed to express their own ideas with longer turns and diverse answers.

In Extract 6 the first question which is followed by a short answer of student is regarded as a convergent question because the teacher wants to encourage whole-class participation before moving on to a new lesson or instructional point. But another student's answer to the second teacher's question (why?) makes it a divergent question because the student uses his own information. The teacher's first question in Extract 5 forms divergent questioning which maintains the Notional Talk in the subsequent turns $(03 \mathrm{~T}, 05 \mathrm{~T})$.

Overall, teacher talk in writing classes is Focal-oriented. The frequency analysis in this study showed that the Focal Talk makes up the largest proportion of writing teacher talk (55 percent) in the first half of the writing courses, comprising four sessions of the IELTS writing course. In the second half or other four sessions of this writing course, it is also the dominant discourse but other episodes of teacher talk appeared more in teacher talk (see Figure 1).

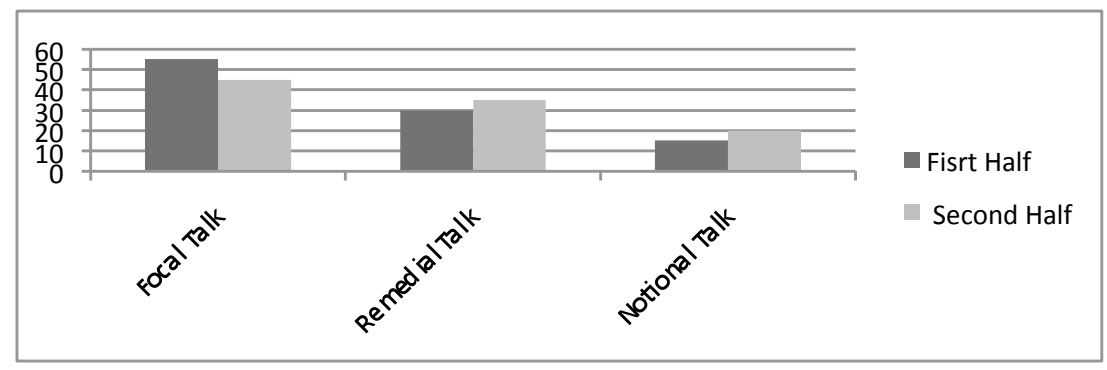

Figure 1: Proportion of episodes in two halves of the writing course 
Varying during teaching, the purpose of writing teacher talk shapes the type of episode and any change to it makes an episode switch. The most common episode switch in the current study was related to Notional-to-Focal ( $\mathrm{N} \mathrm{t} \mathrm{F}$ ) which was followed by Remedial-toFocal (R t F) and Remedial-to-Notional

$(\mathrm{R} \mathrm{t} \mathrm{N})$ transitions. Figure 2 illustrates an overall breakdown of episode switches of WTT by percentage.

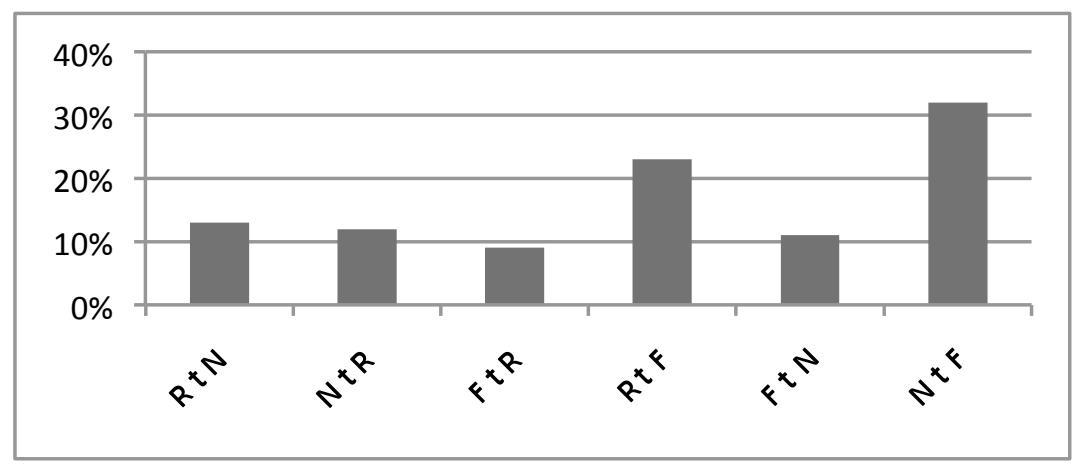

Figure 2: The proportion of episode switches in WTT

As mentioned before and shown in table 1, all three episodes share two micro-episodes carrying two pedagogical functions: ideational and linguistic. A frequency analysis of two writing courses (the IELTS writing and Essay for TEFL students) revealed that the latter micro-episode quantitatively far outweigh the former one in that 25 percent of writing teacher talk covered the ideational or conceptual issues of compositions and essay topics. A large percentage of writing teacher talk ( 75 percent) was focused on linguistic coverage of writing sessions (See table 5). Furthermore, the ideational or conceptual coverage of composition and essay classes was significantly fulfilled by code-switching. On another reading, teachers remarkably had to switch to the Farsi language for explaining about ideas and concepts in writing classes while this code-switching was applied to just 10 percent of the linguistic domain of writing teacher talk to teach items such as vocabulary and grammar.

Table 5: The proportions of WTT Micro-episodes

\begin{tabular}{|l|c|c|}
\hline Micro-episodes Counts & Linguistic Talk & Ideational Talk \\
\hline $\begin{array}{l}\text { Overall Quantity ( 8 sessions of Advanced } \\
\text { Academic Writing and 7 sessions of Basic Writing) }\end{array}$ & $75 \%$ & $25 \%$ \\
\hline Basic Writing & $85 \%$ & $15 \%$ \\
\hline Academic Writing & $65 \%$ & $35 \%$ \\
\hline Switched to the First Language & $10 \%$ & $40 \%$ \\
\hline
\end{tabular}


Put simply, teachers showed a clear tendency to resolve the ambiguity and intricacy of some arguments and concepts by switching to the first language, Farsi, as opposed to just about 10 percent of linguistic concerns expressed in mother tongue explicitly. It is worthy of note that since beliefs and arguments are inherent components of an advanced academic writing course, the rate of their coverage in teacher talk in this writing aimed at resolving the ideas significantly exceeded that of two introductory writing courses run for Law and TEFL students. In percentage terms, ideational talk made up about $35 \%$ and $15 \%$ of microepisodes of teacher talk for Academic and General English respectively.

\section{Discussion}

The disproportionate share of ideational talk (25\%) emerging mostly in Remedial and Notional episodes of WTT compared with linguistic talk (75\%) proves the Inhibition Hypothesis put forward by Schoonen, Snellings, Stevenson and Van Gelderen (2009), according to which the resource-demanding nature of linguistic processing to deploy correct grammar and appropriate lexical items in EFL composition constrains the opportunities to attend to the conceptual aspects of FL writing.

The distinct feature of Focal talk is giving new instruction with new components to student writers. Thus, it can be regarded as the bottom line of teacher talk as it has decisive effects on the quality and quantity of other pedagogical episodes of writing teacher talk. However, rarely is the Focal episode switched to other episodes in an immediate context, inasmuch as it is followed by writing practices or reading activities. The first two frequent switches, Notional-to-Focal, Remedial-to-Focal, are made to introduce a new issue or lesson once the teacher intentionally checks students' current understanding or wants to correct students' mistakes. But Remedial-to-Notional transition is applied when the writing instructor tends to evaluate the learning degree of student writers after covering their problems.

As the Notional episode of teacher talk deals with the evaluation of students' writing quality, this episode can mostly affect future writings. So, a skilled writing instructor normally tries to motivate learners by many techniques of feedback such as conferencing, encouraging an element of group feedback and using careful language. Questioning, which shapes the main and starting part of Notional Talk, should be applied skillfully. Teachers should organize their questions purposefully to generate more participation and consequently more student writers' ideas.

When teacher talk is directed to writing samples, texts and paragraphs, it creates more students interventions appearing more in Remedial Talk. Mindful teachers can transform the individual written feedback on one student's writing to a Remedial Talk episode for all class, hence triggering Notional or Focal episodes and consequent awareness enhancement in a dialogically symmetric atmosphere. On this occasion, as Cumming (1996) assumes, mutually rich spoken discourse, in which the sequence of transactions of problem identification, negotiation and resolution forms, is likely to happen. This opportunity blends the monolithic transmission of knowledge in teaching writing through presentation-practice modes with distributed cognition, which means that goal accomplishment is driven from collaboration among participants. Despite abundant linguistic constraints, teachers should 
not find talking about concepts and arguments irrelevant but should include it in their instruction to speed up student writing and also boost writing for learning as an ultimate goal after students are encouraged to learn to write initially. Further, 'Reactive teaching', which assumes a willingness on the part of the teachers to abandon a degree of pre-determined teaching to cover "the on-line needs of their learners" (Thornbury 2002: 103), can be shaped by both Notional and Remedial episodes of writing teacher talk. In particular, the former is of critical importance inasmuch as it can reveal the students' current understanding of the involving criteria in writing and makes clear whether a new material through Focal Talk should be taught. The latter, however, practically minimizes the mismatch between goals of instruction and students' learning for optimum coverage, and attaches a formative role to the participation of student writers in teaching composition.

In addition, teachers by their expertise can make student writers change their role from being the receivers to the generators as it happened more in the second half of the writing course, The IELTS writing, when more Remedial and Notional episodes were detected. This study also proved that writing teacher talk holds the potential for coverage of the multidimensional aspect of EFL writing but the degree of its pedagogical function varies regarding the needs of the context and proficiency of the teacher. What is more, as Vengadasamy (2002) asserts, a writing tutor can provide either directive response for the instructional purposes or facilitative feedback which motivates writers in a collaborative atmosphere and appears constructively more useful.

\section{Conclusion}

The primary purpose of the study was to find out the pedagogical functions of teacher talk in writing sessions. Three distinct episodes were identified: Focal, Remedial, and Notional talk, which cater for teaching new materials, correcting the misunderstood, and evaluating the learning conditions respectively. The achieved results have provided empirical evidence for the claim of Beck (2010) by which she finds writing skill a three dimensional skill in which cognitive, textual, and social resources are coincidently presented. In other words, writing teacher talk in an EFL context is oriented around thinking process and knowledge transformation of writers, their linguistic demands, and finally concepts and audience in their writings.

As to micro-episodes, the ideational talk compared with the linguistic talk receives scant attention in three detected pedagogical episodes of EFL writing teachers' oracy. Also, the Remedial Talk, especially when it coincides with text-shared teaching or text-directed teacher talk, can bring about more student talk and participation, which are of crucial importance to instructors for investigating and consequently meeting the writing needs of novice writers. Text-directed teacher talk pushes learners to talk more, especially when they express their ideas or engage in a discussion. Swain (1985) in her Output Hypothesis, finding comprehensible input insufficient unless it becomes intake, emphasizes the role of outcome in second language acquisition. Learners can develop their language proficiency when they are pushed to say and write things or are encouraged to use the language exposed to them in meaningful ways. 
The degree of writing teachers' pedagogically discoursal episodes may vary according to curricular purposes, the teaching context and expertise of teachers. However, what should be borne in mind is that a pedagogical focus is actively created, maintained and professionally shifted in the discourse of experienced teachers (Seedhouse 2008). Also, writing teacher's oracy can optimally be profiled to address the writers' needs and maximize their learning opportunities. On another reading, the existing imbalance in writing instruction, especially in EFL contexts, can be tackled by qualified expository discourse management through situationally appropriate and goal-directed teacher talk. Inasmuch teacher talk stems from teachers' cognition, beliefs and planning, it can be seriously included in the syllabus of any English teacher training courses to boost EFL composition.

\section{REFERENCES}

Andrews, S.J. (2003). "Teacher language awareness and the professional knowledge base of the L2 teacher", in Language Awareness, 12, 2: 81-95.

Beck, S. (2010). "Composition: Cognitive, textual and social dimensions", in D. Wyse, R. Andrews \& J. Hoffman ( eds.), The Routledge International Handbook of English, Language and Literacy Teaching. Abingdon: Routledge, 159-169.

Breidbach, S., Daniela, E. and Andrea Y. (2011). Language Awareness in Teacher Education: Cultural-Political and Social-Educational Perspectives. Frankfurt am Main: Peter Lang.

Chadwick, T. (2012). Language Awareness in Teaching: A Toolkit for Content and Language Teachers. Cambridge: Cambridge University Press.

Cullen, R. (1998). "Teacher talk and the classroom context", in ELT Journal, 52, 3:179-187.

Cumming, A. (1996). "Tutoring second language text revision: Does the approach to instruction or the Language of communication make a difference?", in Journal of Second Language Writing, 5, 3: 197-226.

Ellis, R. (2003). Task-based Language Teaching and Learning. Oxford: Oxford University Press.

Foster, P., Tonkyn, A. and Wigglesworth, G. (2000). "Measuring spoken language: A unit for all reasons", in Applied Linguistics, 21, 3: 354-75.

Fraenkel, J. and Wallen, N. (2003). How to Design and Evaluate Research in Education. New York: McGraw-Hill.

Hale, C. (2011). "Breaking with the IRF and EPA: Facilitating student initiated talk", in A. Stewart (ed.), JALT2010 Conference Proceedings. Tokyo: JALT.

Hall, G. (2011). Exploring English Language Teaching: Language in Action. Abingdon: Routledge.

Lincoln, Y.S. and Guba, E .G. (1985). Naturalistic Inquiry. Newbury Park, CA: Sage Publications.

Murray, H. (2002). "Developing language awareness and error detection: What can we expect of novice trainees?", in Trappes-Lomax,H. and G. Ferguson, (eds.) Language in Language Teacher Education. Amsterdam: John Benjamins, 187-198.

Nakaruma, I. (2008). "Understanding how teacher and student talk with each other: an exploration of how "repair" displays the co-management of talk-in-interaction", in Language Teaching Research, 12, 2: $265-283$. 
Nizegorodcew, A. (2007). Input for Instructed L2 Learners: The Relevance of Relevance. London: Multilingual Matters.

Nunan, D. (1991). Language Teaching Methodology: A Textbook for Teachers. Cambridge: Cambridge University Press.

Richards, J.C. and Lockhart, C. (2007). Reflective Teaching in Second Language Classrooms. Cambridge: Cambridge University Press.

Schoonen, R., Snellings, P., Stevenson, M. and van Gelderen. A. (2009). "Towards a blueprint of the foreign language writer: The linguistic and cognitive demands of foreign language writing”, in R.M. Manchón (ed.), Writing in Foreign Language Contexts: Learning, Teaching, and Research. Clevedon, UK: Multilingual Matters, 77-101.

Seedhouse, P. (2008). "Learning to talk the talk: Conversation analysis as a tool for induction of trainee teachers", in K. Richards and S. Garton (eds.), Professional Encounters in TESOL: Discourses of Teachers in Teaching. Basingstoke: Palgrave Macmillan, 42-57.

Stern, H. H. (1983). Fundamental Concepts of Language Teaching. Shanghai: Shanghai Foreign Language Education Press.

Swain, M. (1985). "Communicative competence: Some roles of comprehensible input and comprehensible output in its development", in S. Gass and C. Madden (eds.), Input in Second Language Acquisition. Rowley, Mass: Newbury House, 235-256.

Thornbury, S. (2002). "Training in instructional conversation", in H. Trappes-Lomax and G. Ferguson (eds.), Language in language teacher education. Amsterdam: John Benjamins.

Vengadasamy, R. (2002). "Responding to student writing: motivate, not criticize", in GEMA Online ${ }^{\mathrm{TM}}$ Journal of Language Studies, 2, 1: 39-47.

Walsh, S. (2002). "Construction or obstruction: teacher talk and learner involvement in the EFL classroom", in Language Teaching Research, 6, 1:3-23.

Walsh, S. (2006). Investigating Classroom Discourse. Routledge: London and New York.

Warford, M. K. (2007). "L1 vs. L2 in the foreign language classroom: New findings", in NECTFL Review, 60: 50-67.

\section{ACKnowledgement}

Our sincere thanks go to Negin Ostadsarei and Hossein Jahanifard for their kind support and University of Guilan for the express permission to run the major phases of the study.

\section{Role of the Funding Source}

This study has been supported by a grant offered by Payam-e- Nour University of Iran as the study sponsor in the decision to submit the paper for publication. 